THE OLIVIERI SYMPOSIUM

\title{
Biomedical conflicts of interest: a defence of the sequestration thesis - learning from the cases of Nancy Olivieri and David Healy
}

A Schafer

J Med Ethics 2004;30:8-24. doi: 10.1136/jme.2003.005702

Correspondence to: Professor Arthur Schafer Centre for Professional and Applied Ethics, University of Manitoba, 220 Dysart Road, Winnipeg, Manitoba, Canada R3T 2M8;

Schafer@cc.umanitoba.ca

September 2003

\begin{abstract}
No discussion of academic freedom, research integrity, and patient safety could begin with a more disquieting pair of case studies than those of Nancy Olivieri and David Healy. The cumulative impact of the Olivieri and Healy affairs has caused serious self examination within the biomedical research community. The first part of the essay analyses these recent academic scandals. The two case studies are then placed in their historical context-that context being the transformation of the norms of science through increasingly close ties between research universities and the corporate world. After a literature survey of the ways in which corporate sponsorship has biased the results of clinical drug trials, two different strategies to mitigate this problem are identified and assessed: a regulatory approach, which focuses on managing risks associated with industry funding of university research, and a more radical approach, the sequestration thesis, which counsels the outright elimination of corporate sponsorship. The reformist approach is criticised and the radical approach defended.
\end{abstract}

$\mathrm{T}$ he leading individual roles in this diptych are taken by two internationally eminent medical researchers, haematologist Nancy Olivieri and psychiatrist David Healy. The institutional players include one research intensive university (the University of Toronto) and two affiliated research intensive teaching hospitals (the Hospital for Sick Children, referred to as "Sick Kids" or "Sick Kids Hospital" and the Centre for Addiction and Mental Health, referred to as "CAMH"). The cast of supporting characters is large. On one side are senior hospital administrators and medical faculty deans, together with hospital and university presidents and boards of directors. On the other side is to be found a small group of medical scientists, supported primarily by the Canadian Association of University Teachers (CAUT).

Not coincidentally, the Olivieri and Healy scandals share in common a number of key elements:

- Wealthy and powerful drug companies hover in the background of both, and sometimes occupy a good deal of the foreground, as well: Apotex in the case of Olivieri, Eli Lilly in the case of Healy.

- These drug companies not only fund university and hospital researchers, they are also major donors to the institutions within which researchers carry out their clinical studies.

- Neither Apotex nor Eli Lilly was happy to have adverse information about their drugs publicised.

- Both Olivieri and Healy personally experienced serious negative consequences from their willingness to speak publicly about potential dangers to patients.

- Each of them appealed for assistance, unavailingly, to the senior administrators of the University of Toronto and its Faculty of Medicine. Although there had been a changeover of university presidents and medical faculty deans in the interval between these two scandals, personnel changes made very little difference to the university's official response.

- In both scandals, university and hospital officials failed to recognise that there had been a fundamental violation of the principle of academic freedom at the affiliated hospitals.

- In both cases, the whistleblowing physicians found themselves removed from their positions: Olivieri was fired from her position as director of the Hemoglobinopathy Research Program at Sick Kids' Hospital; Healy's employment contract with both CAMH and the University of Toronto's Department of Psychiatry was terminated.

- Both hospitals and the university denied strenuously that these "firings" were in any way related to the whistleblowing.

- Damaging rumours were circulated among Olivieri's colleagues, including allegations that she was scientifically incompetent, guilty of stealing money from her research grants, unethical in her patient care and sleeping with some of the scientists who looked favourably on her research findings ${ }^{1}$; damaging rumours were circulated about Healy that he was a bad clinician, and both a racist, and a member of a cult known as Scientology. A journalist who telephoned me for an interview at the height of the Healy controversy asked whether I knew that Healy was a prominent Scientologist. Her previous interviewee had been a hospital spokesperson who was circulating that piece of disinformation among the media, presumably in an effort to discredit Dr Healy.

- The perpetrators of these false but damaging accusations against Olivieri and Healy mostly preferred to remain anonymous.

Two of the world's most respected blood researchers, David Nathan of Harvard and David Weatherall of Oxford, writing in The New England Journal of Medicine, describe the Olivieri affair as a "debacle ...complicated by personal animosity, poor administrative judgment, and bad behaviour among academic colleagues". ${ }^{2}$ However, the authors pointedly caution the biological research community not to dismiss the affair as a mere aberration since, they suggest, there is "growing evidence that things may not be much better, albeit less bizarre, elsewhere" (Nathan DG, et al, ${ }^{2}$ p 1370). Nathan 
and Weatherall identify close partnerships between universities and the pharmaceutical industry as a crucial factor in generating such moral crises, both at the University of Toronto and elsewhere.

Surprisingly, however, Drs Nathan and Weatherall conclude their NEJM commentary with an apparent endorsement of scientific commercialisation:

\section{We now have the potential to enter one of the most productive periods of biomedical research, the success of which will depend to no small degree on an increasingly close partnership between universities and industry. (Nathan DG, et al, ${ }^{2} p$ 1370)}

Since commercialisation of university research is the very process which Nathan and Weatherall themselves identify as responsible for having undermined university integrity in the Olivieri affair, the reader is entitled to feel nonplussed. This apparent disconnection between analysis and prescription, puzzling as it may seem to an outsider, reflects a developing consensus within the biomedical research community. The consensus view, strongly promoted by editors of several leading general medical journals, holds that there is nothing inherently wrong or improper about the connubial relationship between universities and industry, so long as the union is properly regulated and managed.

Steven Lewis and his fellow authors of "Dancing with the porcupine" $e^{\prime 3}$ also fall within the developing consensus and, once again, the reader is presented with a perceptive analysis of the problems generated by academic industrial collaborations, oddly combined with an anaemic prescription concerning how best to deal with such problems. Thus, Lewis et al recognise that the basic commitment of universities diverges sharply from the basic commitment of corporations: "The duty of universities is to seek truth. The duty of pharmaceutical companies is to make money for their shareholders." They go on to describe at least some university/industry partnerships as "an unholy alliance whereby researchers and universities become handmaidens of industry" (Lewis S, et al, ${ }^{3}$ p 783). Nevertheless, when it comes to answering the question: "What is to be done?" the authors hasten to reassure the scientific community: "We are not asking academic researchers to forswear all interactions with industry. We are merely proposing rules for exercising due diligence to protect the essence of academic inquiry" (Lewis s, et al, ${ }^{3}$ p 783).

The Porcupine authors adopt the view that it is OK to dance with porcupines if one does so carefully. By analogy, it is OK for scientists and universities to partner with industry, so long as precautions are taken. The suggestion is that if the right regulatory framework is created then the behaviour of industry will "improve voluntarily," "enlightened companies" will adopt "honourable codes of conduct," and cynicism toward industry sponsorship of research will no longer be warranted (Lewis S, et al, ${ }^{3}$ p 783).

Readers of a mildly sceptical disposition may wonder, however, whether "due diligence" is the proper response to an "unholy" alliance between institutions each of which has a fundamentally different and potentially contradictory mission. If the threat to research integrity and patient safety is as serious as the available evidence suggests (see below), then the danger posed to universities and hospitals by commercial partnerships might be better compared to swimming with sharks than to dancing with porcupines. Granted, those who wish to dance with porcupines must exercise extreme caution in order to avoid painful skin punctures, but those who swim with sharks may find that they have become little more than shark bait. To avoid such a cruel fate for our leading universities and their researchers, it might be necessary to decline the swimming invitation altogether. Returning to the porcupine metaphor: there are some dances which it might be better to sit out if one values one's integrity.

Proponents of university/industry partnerships may argue, on the contrary, that instead of business values undermining the integrity of university research, the values of the academy might, instead, elevate morally the conduct of business. Steven Lewis, for example, claims that the involvement of universities in the commercialisation of research has the potential, if accompanied by hardnosed management of the relationship and an acknowledgement of possible dangers, "to keep corporations honest, to ensure that a wider perspective is brought to bear, to create products that might otherwise not see the light of day in a purely private sector milieu" (S Lewis, personal communication, 2003). One must concede that there is no logical impossibility attaching to the hypothesis that the marriage between universities and the corporate sector could produce a "levelling up" rather than a "levelling down" effect. Theoretically, university/industry partnerships might help to produce the "soulful corporation" extolled in some business ethics textbooks. Practically speaking, however, the available evidence shows many cases in which the partnership has had a corrosive effect upon universities and researchers. Evidence to show the opposite effect-the transformation of corporations in an altruistic direction-seems rather thin on the ground. This may not be a decisive objection, however, since the absence of evidence showing the existence of the alleged beneficent effect of university/industry partnerships on the commercial partner could be attributable to the fact that no one has thought fit to investigate this question, or to the practical difficulties of doing so. How would one ascertain whether or not altruistic uplift actually occurs, let alone quantify it? (This argument was suggested to me by Steven Lewis.)

The argument presented in this paper concludes that the deep malaise in our research universities, exposed in its most acute form by the Olivieri and Healy cases, is not likely to be resolved adequately through the kind of risk management strategies currently advocated by the new consensus. If one is determined to protect core university values of research integrity and academic freedom then reformist measures such as (a) disclosure of conflicts of interest and (b) regulation of contracts between researchers and companies, are not likely to do the job. Instead, there needs to be something close to an outright prohibition on the much vaunted "partnerships" between university researchers, on the one hand, and the pharmaceutical industry, on the other.

What follows next is a discussion and analysis of some issues raised by the Olivieri and Healy cases, respectively.

\section{NANCY OLIVIERI AND THE HOSPITAL FOR SICK CHILDREN}

Accounts of the Olivieri/Apotex/Sick Kids Hospital/University of Toronto controversy have multiplied and divided to the point where they would now overfill the shelves of a reasonably sized library. The "Naimark report" (1998), commissioned by the Hospital for Sick Children, took several hundred pages to document its claim that if anyone was at fault in this sorry tale it was Dr Nancy Olivieri. No criticism is directed toward either the hospital or the university for their failure vigorously to support Olivieri's academic freedom.

Significant parts of the testimony on which Naimark based his findings were later shown to be incorrect. ${ }^{5}$ It took some time, however, for the historical record to be authoritatively established and, in the interim, because of the adverse findings of the Naimark report, Olivieri was charged with "research misconduct" and was thereupon referred, amidst 
great publicity, first to the medical advisory committee of her own hospital, and subsequently to the College of Physicians and Surgeons of Ontario. Olivieri's patient care was then thoroughly scrutinised by the college. When the Ontario College Committee of Inquiry finally reported, it exonerated her of all charges, and found her conduct to have been exemplary. Unfortunately for Olivieri, the highly publicised referral to the college, together with repeated attempts to dismiss her, forced her to endure years of public humiliation before the charges of unprofessional conduct were exposed as baseless.

Serious doubts about the objectivity of the Naimark inquiry were raised as soon as it was established, and doubts about the accuracy of its report surfaced almost immediately after its publication. Naimark was appointed unilaterally by the hospital, over the objections of Olivieri and her supporters. The latter favoured an investigation conducted by a panel whose composition both sides could accept as impartial and objective. After a good deal of public controversy, the hospital decided to allow Naimark, at the midway point of his inquiry, to recruit two additional panel members; but Olivieri was allowed no input as to their identity. She and her supporters boycotted the entire proceedings as a public demonstration of their lack of confidence in the process by which the inquiry chair and his two fellow panellists were chosen. Evidence that the Naimark report's authors had relied on false, misleading, and heavily biased information led to the launch of a second inquiry, this time commissioned by the Canadian Association of University Teachers. ${ }^{5}$ Thompson and his coauthors insisted that they operate independently of CAUT and insisted also that their report be published without alteration. The Canadian Association of University Teachers accepted these conditions. This inquiry was able to draw on much information unavailable to Naimark, and the 540 page report it published, known as the Thompson report, reached conclusions very different from those of Naimark. Here are a few of their findings, all taken from page 29 of the Thompson report:

Apotex issued more legal warnings to deter Dr Olivieri from communicating this second unexpected risk of $\mathrm{L} 1$ to anyone. However, she was legally and ethically obligated to communicate the risk to those taking, or prescribing the drug as there were potential safety implications for patients, and she fulfilled these obligations despite the legal warnings.

Apotex acted against the public interest in issuing legal warnings to Dr Olivieri to deter her from communicating about risks of L1. None of the legal warnings have been rescinded.

Apotex's legal warnings violated Dr Olivieri's academic freedom.

The Hospital for Sick Children and the University of Toronto did not provide effective support either for Dr Olivieri and her rights, or for the principles of research and clinical ethics, and of academic freedom, during the first two and a half years of this controversy. After the controversy became public in 1998, the university stated publicly that it had provided effective support for Dr Olivieri's academic freedom, but this was not true.

The Hospital for Sick Children and the University of Toronto did not provide effective support either for $\mathrm{Dr}$ Olivieri and her rights, or for the principles of research and clinical ethics, and of academic freedom, during the first two and a half years of this controversy. (Thompson J, et $\left.a l_{,}^{5} \mathrm{p} 29\right)$
Not surprisingly, given the intensely polarised atmosphere in which this dispute was played out, Naimark responded to the Thompson report's findings by flatly refusing to concede that his own report was seriously deficient.

Naimark and the two academics with whom he collaborated on his report then attempted to rebut some of the CAUT report's findings, ${ }^{6}$ and the authors of the CAUT report have, in turn, challenged Naimark's evidence and arguments. ${ }^{7}$ Fortunately, at least for those who prefer clarity to confusion, the report of the Ontario College of Physicians and Surgeons, settled many of these disputed matters by authoritatively clearing Olivieri of the charges made against her by Naimark and by the medical advisory council of Sick Kids Hospital. ${ }^{8}$ The college's findings were "authoritative" in a legal sense, because it has legislative authority in such disciplinary matters. They were also widely seen as "above the battle", which gave their findings a kind of moral authority. But their jurisdiction was limited, and they could not adjudicate many of the important issues. By exonerating Olivieri and praising her professional conduct, the Ontario college report made it much more likely that Sick Kids Hospital and the University of Toronto would finally move towards a settlement with Olivieri and her scientific supporters. Such a settlement was reached in the autumn of 2002, a mere six years after the conflict became a national and international cause célèbre.

The reports and counter-reports, arguments, and rebuttals, have all been widely splashed on the internet and in the mass media. As well, news reports of the affair, together with editorials and commentaries, have appeared in many leading medical journals, including the New England Journal of Medicine, the Lancet, Nature, Science, the Journal of the American Medical Association, and the Canadian Medical Association Journal. The Canadian Medical Association Journal published a concise review of both the Naimark and Thompson reports. ${ }^{9}$ Hundreds, probably thousands of articles on the scandal have appeared in the Canadian and international press. Lawsuits have proliferated almost as rapidly. News stories and documentaries on radio and television have filled the airwaves. British novelist John le Carré published a novel based loosely on the facts of the Olivieri case, ${ }^{10}$ and Hollywood producers are rumoured to be interested in turning this drama into a blockbuster movie.

Yet, despite the apparent complexity of the facts and circumstances surrounding the scandal, the Canadian public almost immediately understood the gist of the underlying ethical issues. With seeming indifference to the campaign of vilification against Olivieri-a campaign which questioned her scientific competence, her ethics, her personality, and even her sanity-both the scientific community and the general public appeared intuitively to understand that when Olivieri spoke out publicly about perceived dangers to her patients, she was acting in a manner consistent with the highest traditions of her profession. This subjective judgment about popular perceptions of the scandal is based upon reports and commentaries in medical/scientific journals, and supported by an unscientific survey of letters to the editor and callers to open line radio shows in Canada.

In short, notwithstanding the proliferation of competing reports, the rights and wrongs of the Olivieri/Apotex dispute are not so very complicated or difficult to comprehend. Indeed, they can be encapsulated in a few sentences. (1) Once Dr Olivieri came to believe, based on scientifically credible preliminary evidence, that the experimental treatment she was administering might cause unanticipated harm to some of her patients/research subjects, she was duty bound to disclose those risks. (The risks of harm were discovered by serial liver biopsy, but actual harm, were it to occur, would be expected to occur very gradually over a period of many years.) (2) Olivieri's university and her hospital had a corollary duty 
to support her request for assistance in this exercise of academic freedom and in the performance of her obligations as a physician and a researcher. Their failure to provide this support in an effective manner raises important questions about the way in which society funds biomedical research institutions and biomedical research.

Every version of the Hippocratic Oath, from ancient times down to the present day, has had, as its leading principle, some version of the maxim that "the life and health of my patient will be my first consideration". Thus, whether or not Dr Olivieri is ultimately proven to have been correct in her negative interpretation of the preliminary scientific data, once her data indicated the possibility of unanticipated harm, she was morally obliged to inform her patients of this risk. Writing in the New England Journal of Medicine, two blood science researchers, David G Nathan, of Harvard's DanaFarber Cancer Institute and David J Weatherall, of Oxford University, comment that: "a]s of this writing, the safety and efficacy of deferiprone have not been established". They suggest that it takes years of careful monitoring before the effectiveness of any iron chelator is clinically established; but they then go on to remark that: "Suffice it to say, when the dispute began, Olivieri had good reason to believe that deferiprone was neither safe nor effective" (Nathan DG, et al, ${ }^{2}$ p 17). (Since Apotex discontinued the clinical trial prematurely, no conclusive scientific evidence exists, and the scientific aspect of the controversy remains unresolved.)

One important qualification should be appended to this claim. Given that the stakes were high, both for the patients/ research subjects and for the drug company, Olivieri had an obligation to exercise due diligence by consulting qualified colleagues about her interpretation. This she did, and they supported her concerns. (Apotex, however, most definitely did not agree with Olivieri's interpretation of her data, and the company was supported in its favourable interpretation by a number of scientists receiving financial support from them.) It would then be the responsibility of patients to weigh the hoped for benefits against the possible risks of harm. Respect for the value of patient autonomy clearly requires that those patients who are also research subjects be given all materially relevant information in order to enable them to decide whether they wish to continue participating in a clinical trial. It should go without saying that the information to which patients are morally and legally entitled includes information about risks of harm which comes to light during the course of a clinical trial.

Olivieri also had ancillary obligations to report any newly discovered risks to the research ethics board of her hospital and to share her findings with other researchers, both at scientific meetings and in peer reviewed journals. Only in this way could her colleagues, worldwide, test and assess her conclusions and properly inform their own thalassaemia patients of newly discovered potential risks. In every case, Dr Olivieri behaved in the manner required by her professional obligations, though she, and the core group of colleagues who supported her, paid a heavy career and personal price for doing her/their duty. Dr Brenda Gallie, Dr Helen Chan, Dr Peter Durie, and Dr John Dick were all colleagues of Olivieri at the Hospital for Sick Children. All supported Olivieri in her struggles with Apotex, Sick Kids Hospital, and the University of Toronto, despite serious risks of harm to their own careers. ${ }^{5}$ It is difficult not to empathise with Olivieri when she laments: "It should not be so hard to protect children at Sick Kids Hospital". This sentence was quoted by a colleague and supporter of Olivieri, Dr Paul Ranalli, in a letter published by the Globe and Mail, headed "Courage under fire". ${ }^{11}$

It is true, of course, that Apotex had a legal contract with Dr Olivieri, which was signed in 1995. That contract contained a confidentiality provision-one that prohibited her from disclosure "to any third party" of data from her Apotex sponsored clinical trial of the drug deferiprone, without the express permission of the company, for a period of three years after the termination of the trial. The nondisclosure clause of the LA-01 contract between Olivieri and Apotex reads as follows:

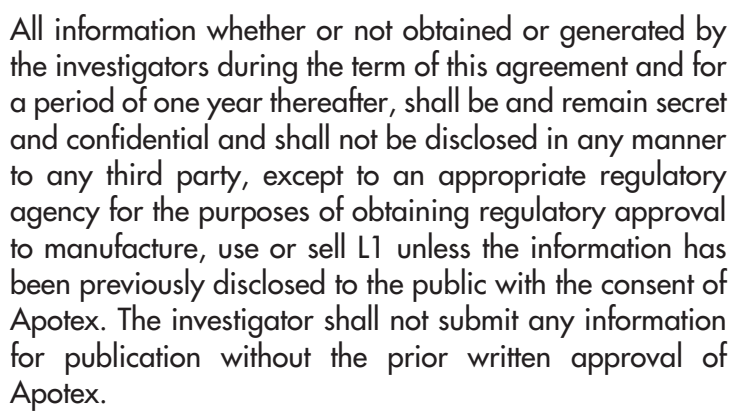

This clause, it should be noted, does not specifically list "patients", but they would clearly appear to be covered under the phrase "any third party". Olivieri claims, supported by tapes of telephone conversations with Apotex, that Apotex threatened repeatedly to sue her if she breached the confidentiality clause of the contract, and that they warned her not to disclose her concerns to patients and others.

At the time Olivieri signed the contract such nondisclosure provisions were common. Olivieri readily admits that she failed to appreciate the potential significance of that contract, and concedes that she should never have signed it. The University of Toronto admits that it was guilty of an institutional oversight by permitting its researchers to agree to such terms, and the university subsequently took steps to preclude repetition by any of its faculty.

Because Apotex refused, repeatedly, to give permission for disclosure, Olivieri might have been found legally liable for significant damages arising out of her disclosure of risks to her patients and colleagues.

Since the protection of human life is, other things being equal, a higher value than respect for the sanctity of contracts, it is possible that the legal system would have "thrown out of court" any lawsuit for breach of contract brought by Apotex against Olivieri, as being against public policy and, hence, unenforceable. For our purposes, it matters little whether the non-disclosure provision of the contract Olivieri signed with Apotex would have been found by the courts to be nugatory. Nor, for our purposes, does it matter much whether the information Olivieri disclosed to patients and colleagues was information actually covered by the terms of the confidentiality agreement she signed-an issue also in dispute. Even if Nancy Olivieri were legally bound to keep confidential all information about the risks of deferiprone, she was morally obliged to disclose that information to her patients and to her colleagues worldwide. It could be argued, of course, that one has a moral obligation to keep the contracts one signs. This moral obligation is prima facie, however, rather than absolute, and should surely be overridden where the lives and health of patients are at stake.

Apotex did not agree with Olivieri's interpretation of her data and they refused her request to disclose these risks to her patients. They also threatened to take legal action against her if she were to violate the non-disclosure clause of the contract. Olivieri proceeded anyway, in the face of these threats, to disclose her findings, and some time after these events, the company did take legal action against her. On 24 May 1996-for example, Apotex wrote to Olivieri that it was terminating both of the clinical trials she was conducting for 
them, and warned her not to disclose information "in any manner to any third party except with the prior written consent of Apotex", and warned further that it would "vigorously pursue all legal remedies in the event that there is any breach of these obligations" (Thompson $\mathrm{J}$, et al, p 143). Just prior to their suing her, she sued them for defamation.

According to one standard account of heroism, the hero is a person who acts far beyond the call of duty. By this test, Olivieri's actions would not count as heroic. She only did that which it was her duty to do. But there is another account of heroism according to which the hero is a person who does her duty, at great risk to her own self interest, when most others would resist from fear. Olivieri relates a story about her personal fears. Sitting in a restaurant with her scientific collaborator, Dr Garry Brittenham, she raised the concern with him that if they were to break their contract with Apotex by disclosing to patients the risks they had newly discovered, Apotex might act on its threats to sue, and the enormous costs of fighting such a lawsuit could mean that they would each lose their homes. Brittenham replied: "Red wine or white?" At that moment, Olivieri reports, it became obvious to her that there was no decision to make concerning whether or not to disclose. They had to disclose the risks. Better, therefore, to concentrate on those matters that still required a decision, such as the colour of the wine they were to consume with their dinner (The Current, $\mathrm{CBC}$ radio interview, 2 Mar 02).

Apotex is currently suing Olivieri for damages, claiming that she defamed both the company and their drug (deferiprone). Olivieri is suing Apotex for defamation. For the benefit of those who have had the good fortune never to be involved in a legal action of this sort, it is perhaps worth noting that the costs of defending such an action (at least in North America and England) tend to be ruinously expensive; hence, utterly beyond the means of any except the wealthiest individuals. When Olivieri turned to her hospital and university for financial and other help in the face of intimidating threats of legal action against her, they provided little effective assistance (Thompson J, et al, ${ }^{5}$ p 29). Instead, both the University of Toronto and the Hospital for Sick Children "took actions that were harmful to Dr Olivieri's interests and professional reputation, and disrupted her work" (Thompson J, et al, ${ }^{5}$ 32). In their public pronouncements about the case, none of the senior administrators of the university, the medical faculty, or the hospital gave any sign that they recognised that the case was one involving a serious issue of academic freedom. They justified their official "tread lightly" policy in part by characterising the conflict as a "scientific dispute", to be resolved primarily between the parties themselves. Some University of Toronto officials did make efforts, behind the scenes, to promote a settlement between Olivieri and Apotex but, as the Thompson report found, the support which they offered was "not effective".

It was discovered during this period of conflict and controversy that the University of Toronto was negotiating for a twenty million dollar donation from Apotex (with additional millions promised for its affiliated hospitals). Some were led to speculate that the university's failure to recognise and support Olivieri's academic freedom might not have been unconnected to its eagerness to secure financial support from Apotex for the university's proposed molecular medicine building project. Indeed, it was subsequently revealed that the university's then president had gone so far as to lobby the Government of Canada on behalf of Apotex. In a private letter to the Prime Minister of Canada, President Robert Prichard stated that the government's proposed changes to drug patent regulations would adversely affect Apotex's revenues and could thereby jeopardise the building of the university's new medical research centre. President Prichard was unsuccessful in persuading the federal government to change its drug patent laws, but his action demonstrated the lengths to which the university was prepared to go in appeasing the company or promoting its interests. When Prichard's conduct became public knowledge, he apologised to the executive committee of the university for acting inappropriately in this matter (Thompson J, et al, ${ }^{5}$ p 13).

This embarrassing episode illustrates the dangers that can ensue from university reliance upon industry "philanthropy". When career success for university/hospital presidents and deans is measured in significant part by their ability to raise vast sums of money from corporate donors, such fundraising can easily become a dominating priority. In North America, top university and hospital officials are now required to ride two horses: their fundraiser's horse and, simultaneously, their academic horse (as guardians of core university values). Unfortunately, those who attempt to ride two horses can come to grief when, as sometimes happens, the horses pull in opposite directions. Perhaps it is time for a radical rethinking of the competing role responsibilities of top university and hospital officials.

The word "philanthropy" is placed above in warning quotes, not to suggest that big pharma never behaves in a genuinely philanthropic manner but, rather, to flag the point that when corporate donors make substantial donations they often expect to gain substantial influence. Indeed, it is the legally mandated duty of corporate executives and board members to act in the "best interests" of the corporation, which is commonly interpreted to mean that they have a legal duty to maximise overall profitability. Corporate donations to universities are typically viewed, at least in part, as an investment. This, in turn, raises the questions (to which an answer is supplied later): What exactly is being bought by such investments? What exactly is being sold?

\section{DAVID HEALY AND THE CENTRE FOR ADDICTION AND MENTAL HEALTH}

In December of 2000, while the Olivieri affair was still capturing attention, both within and without the University of Toronto, a second major scandal, also raising basic issues of academic freedom and patient safety, was brewing at the same university.

Some months previously, the Centre for Addiction and Mental Health had hired Dr David Healy to become the new director of its Mood and Anxiety Disorders Clinic. After accepting their offer and the offer of a joint appointment in the university's Department of Psychiatry, Healy notified his employer in Wales of his intention to resign, and prepared to move his family to Canada to take up this new appointment. Then, Healy's career plans came dramatically unstuck.

On 30th November 2002, some months before his new appointment was officially scheduled to begin, Healy made a conference presentation at CAMH. (The symposium, called "Looking Back, Looking Ahead", was held to mark the 75th anniversary of the university Department of Psychiatry, as well as the 150th anniversary of the Queen Street Mental Health Service.) In this lecture, which he subsequently delivered at Cornell, and in Paris, Minneapolis, and Cambridge, Healy raised the question of whether the drug Prozac, manufactured by Eli Lilly, might be responsible for increasing the risk of suicide among certain kinds of patients. This issue was by no means the principal theme of Healy's talk, but the potential link of Prozac to patient suicides, and the call for further research on this matter, was almost certainly regarded by CAMH officials as the most controversial part of Healy's presentation. Healy reports that his talk was well received in all the places where he presented it, and 
it is noteworthy that the audience at the CAMH conference honoured his lecture with the highest rating for content. ${ }^{12}$ Despite this fact, senior administrators of CAMH were not well pleased. Within 24 hours of the talk they were trying to contact him. Within a week he received an email unilaterally rescinding their offer of employment.

Why was David Healy's employment terminated so precipitately by both the Centre for Addiction and Mental Health and the university Department of Psychiatry? No one disputes that Healy is an internationally distinguished psychiatrist and researcher. The university and CAMH recruited him with enthusiasm and persistence. Since he was unhired almost immediately after he gave his conference lecture at $\mathrm{CAMH}$, the inference is inescapable that his contract for employment was cancelled because of the contents of his lecture that day. In this lecture, Healy expressed the view, referred to above, that the antidepressant drug Prozac might cause some patients to commit suicide. Although Healy did not condemn Prozac outright, he did advocate caution on the part of doctors who prescribe this drug, and he called for further research into possible adverse side effects. He was also critical of the practice whereby drug companies are engaged in ghostwriting some of the therapeutic literature.

Some time prior to Healy's conference presentation, Eli Lilly had donated 1.5 million dollars to CAMH, and a new wing of the hospital, built with their financial assistance, was scheduled to have its official opening soon after. There is no evidence that Eli Lilly attempted to have Dr Healy fired from his new appointment at CAMH. The incident raises legitimate questions, however, about whether those involved with rescinding his contract offer were affected, consciously or unconsciously, by the relationship between CAMH and Eli Lilly.

In this connection, it is worth noting that six months before Healy delivered his fateful presentation at $\mathrm{CAMH}$, he had published an article on Prozac in the biomedical ethics journal, the Hastings Center Report. ${ }^{12}$ In this article, Healy developed several of the themes which later became controversial at the University of Toronto, namely suicide and Prozac, and ghostwriting of scientific articles by drug companies. Eli Lilly, which had hitherto been the largest annual private donor to the Hastings Center, publisher of the Hastings Center Report, subsequently withdrew its financial support for the centre. ${ }^{13}$

The administrations of both the University of Toronto and CAMH claim that the unhiring of Dr Healy had nothing to do with academic freedom. Instead, they contend, his lecture gave rise to "clinical concerns" and revealed that he would be a "bad fit" with his new colleagues. It may be worth quoting a key paragraph from the email which the University of Toronto sent to Healy by way of explaining their decision to rescind his contract:

\section{Essentially, we believe that it is not a good fit between you and the role as leader of an academic program in mood and anxiety disorders at the centre. While you are held in high regard as a scholar of the history of modern psychiatry, we do not feel your approach is compatible with the goals for development of the academic and clinical resource that we have. This view was solidified by your recent appearance at the centre in the context of an academic lecture. (Healy D, ${ }^{12}$ p 6)}

University of Toronto officials later denied that Healy was unhired because of fears on their part that if Dr Healy were allowed to take up his position drug companies might be reluctant in future to donate money to or fund research at the centre. Notwithstanding their strenuous denials, however, many people understood the above quoted words to mean "... the university was worried about the risk to the financial inflows to the department from pharmaceutical company sources" (Healy D, ${ }^{12}$ p 6).

In September 2001, an international group of physicians published an open letter to the president of the University of Toronto, in which they protested against what they termed the "maltreatment" of Dr Healy. In their open letter they concluded: "To have sullied Dr Healy's reputation by withdrawing the job offer is an affront to the standards of free speech and academic freedom". The signatories, who included two Nobel Prize winners, chose not to focus on the possible involvement of a drug company in university affairs, but they nevertheless insisted that the central issue in the case was the failure of the University of Toronto and CAMH to uphold "the standards of open discussion and frank exchange in university life" ${ }^{14}$ That is, the issue was essentially one of academic freedom.

The university's official response to the concerns expressed by this international group of scholars was dismissive: they (the protesting scholars) were ill informed outsiders, unaware of all the pertinent information. University of Toronto spokespeople went even further in their defence of the unhiring of Dr Healy by suggesting that his publicly expressed concerns were dangerously irresponsible. On the University of Toronto's website, Healy's warnings about the potential hazards of Prozac were compared to the "fool" who cries "fire" in a crowded theatre. ${ }^{15}$ To this accusation, Healy responds: "But what if there is a fire in the theatre?" (Healy $\left.\mathrm{D},{ }^{12} \mathrm{p} 11\right)$ It is worth bearing in mind that Prozac or other drugs of its class, known as SSRIs, are often prescribed to healthy patients with problems in living. If, as Healy believes the evidence indicates, some of these healthy patients become suicidal because of their ingestion of SSRI type drugs, then a failure to warn them and their physicians of this potential side effect would be grossly irresponsible.

The argument underlying such an analogy is, presumably, that Healy's warnings (of possible adverse side effects from taking Prozac) $)^{16-18}$ might deter some depressive patients from using Prozac or other SSRI drugs and this, in turn, might result in their committing suicide. In other words, the university's position seems to be that when the values of clinical care clash with the values of science, the former should trump the latter. The problem with this argument, however, is that if valid it proves too much. It proves that researchers ought never to warn patients of potentially harmful side effects lest some patients thereupon forgo an effective medication.

This manifestation of an approach often labelled "physician paternalism" would be morally objectionable because it would usurp the patient's right to give informed consent to treatment. How can patients weigh and balance the benefits and harms of treatment options (including the option of not taking any antidepressant medication) if evidence about potential harms is deliberately withheld from them? There is by now a vast literature, both legal and ethical, in which the near universal consensus of philosophers and jurists is that competent adult patients have a fundamental right to give informed consent to treatment. In practice, this means that research scientists must make the results of their research public, so that physicians can adequately inform their patients about potential risks. The duty to warn would seem, then, to be a fundamental obligation of every research scientist. Both Healy and Olivieri were alerting patients and the scientific community to the need for further research into potentially serious adverse consequences of the drugs they were investigating. For either to have remained silent about 
their preliminary adverse data would surely have been a violation of their legal, as well as their moral, duty.

Interestingly, on 10 June 2003, the Medicines and Healthcare Products Regulatory Agency [MHRA] of the UK issued a caution to physicians that Seroxat (Paxil) was "contra-indicated" in children under 18 for the treatment of major depressive disorder. Potential side effects include dramatically increased risk of "potentially suicidal behaviour". (G Duff, personal communication, 2003). Thus, it seems that recent evidence further confirms the wisdom of Healy's warnings about drugs of the SSRI category. Sadly, his scrupulous caution appears to have cost him his job at the University of Toronto.

A short time after the university's dismissive rejection of the open letter, described above, Dr Healy initiated what might have been the first legal action in the English speaking world based, in part, on the alleged tort of violating academic freedom. ("Alleged" because until there is a legal precedent in which the courts find that such a tort exists, one cannot be sure of its validity.) A settlement was subsequently negotiated, which included the appointment of Healy as visiting professor in the Department of the History of Medicine (with unrestricted academic freedom to speak out publicly about any of the issues). The appointment as visiting professor of the history of medicine is for one week a year during each of the following three years. He was not permitted, however, to assume the position for which he had originally been hired, as director of the Mood Disorders and Anxiety Clinic of CAMH.

David Healy, himself, feels little doubt about the most important lesson to be learned from his experience at CAMH, and he insists that it is the same lesson that should be learned from the experience of Nancy Olivieri at Sick Kids Hospital: "What is involved is a contrast between the values of science and the values of business" (Healy $\mathrm{D}^{12} \mathrm{p} 11$ ). Although the Thompson report dealt only with the Olivieri case, the Thompson authors, like Healy, conclude that the problem is system wide: "...T] he safety of research subjects in clinical trials and the integrity of the research project are more important than corporate interests" (Thompson J, et al, ${ }^{5}$ p 17). Nathan and Weatherall, in their NEJM commentary on the Olivieri case reach a similar conclusion, ${ }^{2}$ as does Somerville writing in Nature, ${ }^{19}$ and as do the authors of the CMAJ article "Dancing with porcupines". ${ }^{3}$ Together, the Healy and Olivieri cases have forced both the university community and the wider public to confront the ways in which university/industry partnerships can imperil the fundamental values of academic freedom, research integrity, and patient safety.

Before we attempt to analyse potential cures for what appears-from evidence presented below-to be a systemic malaise affecting research universities and hospitals worldwide, it will be useful to step back one or two paces, in an effort to gain some historical perspective.

\section{ANCIENT HISTORY: WHERE WE CAME FROM}

In 1961, ex President Dwight Eisenhower warned his compatriots of the dangers posed to American society by the rise of what he called "the military/industrial complex". At that historical juncture ties between the American military and the arms industry had become so intimate and extensive that Eisenhower-by no means a Marxist revolutionary-felt compelled to speak publicly of his fears for the future of American democracy.

It is not implausible to speculate that were Eisenhower alive today, he might be tempted to issue a comparable warning against "the scientific/industrial complex". The dramatically increased role of for profit corporations in the funding of medical and life sciences research is, arguably, a trend that threatens to undermine both the traditional values of science and the public's trust in our research universities and teaching hospitals. Although this discussion will focus primarily on medical research, the argument advanced could easily be reiterated about research in such diverse fields of study as agriculture and economics. If respected researchers, such as Olivieri and Healy, can experience persecution from their own hospitals and universities for disclosing potential risks to patients, then which other researchers will be brave enough to speak out in a manner likely to attract industry disapprobation?

The fundamental ethos of contemporary scientific research has evolved so rapidly during the past few decades that it would scarcely count as hyperbole were one to describe the process as a "revolution", or perhaps as a "commercial revolution". To offer but one example from a vast range of possible examples outside biomedicine, one recent report describes how the British government is subsidising the oil and gas industry's profits to the tune of about 40 million pounds every year through the "capture" of some of Britain's most respected academic institutions. The report outlines how Britain's universities and colleges are being co-opted into directing their research and training for the benefit of the fossil fuel industry, with potentially devastating long term effects on the environment. Although no branch of inquiry, from agriculture to climate change, has escaped the revolution, the change has been more dramatic in the field of biomedicine than in any other area of university research.

Like most other complex human endeavours, the scientific enterprise has always been norm governed. A classic elaboration of those norms is to be found in the work of Robert Merton. ${ }^{20}$ The picture of scientific culture painted by Merton features several key elements: "universalism," "communism," "disinterestedness," and "organised skepticism". Loosely translated, Merton is claiming that within the scientific community (a) the soundness of scientific research is judged by impersonal criteria; (b) research findings are treated as open and shared rather than secretive or proprietary; (c) researchers are motivated by the pursuit of truth, rather than by financial or career self advancement, and (d) research findings are accepted only after a rigorous process of testing.

Congressional testimony of Dr Jonathan King, Professor of Biology, Massachusetts Institute of Technology, nicely encapsulates and echoes the spirit of science as formulated by Mertonians:

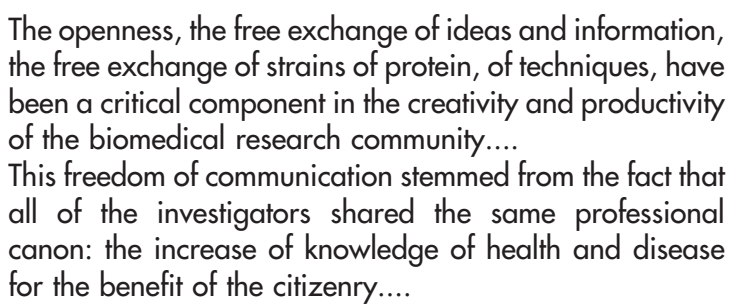

The above excerpt was taken from Commercialization of Academic Biomedical Research (hearing before the subcommittee on investigations and oversight and the subcommittee on science, research and technology of the House Committee on Science and Technology, 97th congress, first session, 1981, 62-63, as cited by R P Merges. ${ }^{21}$

These cultural norms of traditional science are meant, in part, to be descriptive of the actual practice of members of the scientific community, but they are also partly "aspirational". That is, they establish goals or ideals from which actual practice may sometimes fall short. 
It would be naïve to deny that previous generations of scientists were sometimes reluctant to share their ideas, in case a colleague might "steal" them. "Pure" motives, such as intellectual curiosity or the welfare of humankind, were inevitably admixed with such "impure" motives as personal status and career advancement. ${ }^{21}$ Thus, well before the currently prevailing trend towards commercialisation of scientific research, the free sharing of scientific ideas, information, and materials was sometimes honoured in the breach. Members of the scientific community have never been total strangers to such less than elevated motivations as the desire to scoop the competition or win promotion and honours.

Still, even if one concedes that the Golden Age of "science in the public interest" was never quite as pure or golden as some romantics might like to imagine, it seems undeniable that the enormous increase of corporate research funding for university and hospital scientists, over the past half century, has contributed to a profound transformation of the culture of biomedical science.

The recent history of Johns Hopkins University serves as a paradigm case to illustrate what is happening at many North American and British universities. Johns Hopkins, which can plausibly claim to have been America's first pure research university, has only recently embraced commercialisation. Sadly, it compensates for being late to the commercial game with its current unbridled enthusiasm for the entrepreneurial model. From its Quaker origins (1876) until just a few years ago, the ethos prevailing at Hopkins was explicitly antibusiness. Patents were simply not sought on the many important discoveries originating at the university. In 1933 the faculty actually voted, formally, against a proposal that the medical school adopt a policy of owning patents. This Hopkins decision to reject close commercial ties, both for the university and for its researchers, was taken at a time when the anticommercial spirit was still common among elite American research universities. Stanford University and the Massachusetts Institute of Technology were both business friendly; Harvard was not.

William R Brody, who became Hopkins's president in 1997, provided much of the impetus towards shifting the university's ethos in a more entrepreneurial direction. President Brody was certainly aware that the promotion of university/ industry partnerships posed a "minefield of potential conflicts". He nevertheless insisted that "[t]o move your research forward, you've got to do partnerships with industry". ${ }^{22}$ The former vice dean of research at the medical school, Dr Bart Chernow, asserts with unselfconscious pride that Hopkins has become "one of the biggest biotech companies in the world". A few decades earlier, such an utterance would have been received as a shameful admission rather than a prideful boast. Some Hopkins administrators, such as former Vice Dean David Blake, now go so far as to argue that researchers become more productive when they own a large financial stake in the company sponsoring their work: "No conflict, no interest".

Hopkins's researchers and the university itself stand to make millions upon millions of dollars from their ownership of shares in the companies with whom the university has entered commercial agreements. Such arrangements can now be found at many leading American universities. They appear to have become the new norm. A few examples: Stanford University and the University of California, San Francisco, split \$270 million in income from a single genetics invention. Michigan State University earned more than \$160 million from sales of two anticancer drugs. In its anticommercial phase, Johns Hopkins University declined an opportunity to patent a DNA testing method, from which a Bethesda, Maryland, company subsequently earned \$100 million. ${ }^{22}$ For any university to turn its back on moneymaking opportunities of this magnitude requires a willingness to forgo a source of enormous potential income, in the certain knowledge that such income will flow, instead, to other, less scrupulous, competitors. Derek Bok, former president of Harvard University, introduces a somewhat cautionary, note, however: "Most universities have not earned much money from royalties; the odds of making anything substantial from patenting a new discovery are extremely small" ${ }^{23}$

This background helps us to understand how it has come to pass that Johns Hopkins University, historically disdainful of the corrupting potential of commercialised research, is now a marketplace "leader" among universities. Hopkins officials confidently answer those who warn that "the market is corrupting" with the rejoinder: any threat to research objectivity resulting from financial conflicts of interest can be managed by careful regulations. To discourage potential abuse, Hopkins requires that scientists who are engaged in drug trials disclose their financial ties. This contrasts with the somewhat stricter approach taken at Harvard Medical School, which also requires disclosure but which, in addition, does not permit its researchers to have more than a maximum of \$20 000 invested in the company sponsoring their research.

Critics might argue that even the comparatively stern standards prevailing at Harvard are nevertheless unacceptably permissive of financial conflicts of interest. Harvard administrators reply by publicly expressing concern that if Harvard does not move further in the direction of wide open for business universities, such as Johns Hopkins, it will continue to lose some of its best researchers to competitors with more permissive ethical standards. The expression "race to the ethical bottom" might have been coined for just such situations.

The list of indictments which traditionalists raise against the new model entrepreneurial university is already long, and seems to be lengthening rapidly. Critics fear that widescale commercial funding has already produced an erosion of cooperation and community among biomedical researchers. Instead of an easy sharing of knowledge and reagents, one finds something approximating to a quasiHobbesian war of each (laboratory) against all (others). Instead of concern above all for the safety of research subjects and the integrity of research findings, one finds shabby compromises of both these foundational values. Instead of jealously protecting academic freedom and intellectual openness, university administrations become hospitable to censorship and nondisclosure.

Because commercialised research responds primarily to "effective demand" (that is, demand backed by money) in the marketplace, it has also the potential to produce a different kind of challenge to basic social values, as illustrated by the history of the drug eflornithine. Eflornithine was originally developed by the Aventis drug company as a possible treatment for cancer. It proved to be ineffective as an anticancer agent, but highly effective as a cure for sleeping sickness. Unfortunately, the victims of sleeping sickness were mostly people living in the Third World, too poor to bring effective demand to the marketplace. Since the drug could not make a profit, however beneficial (in this case, lifesaving) its results, Aventis discontinued making it. Serendipitously, however, the drug was later discovered to be an effective depilatory, and since there is a robust market in wealthy Western nations for products to remove facial hair, the drug is back in production and is now also being made available at little or no cost to treat sleeping sickness in poor countries. ${ }^{24}$ The twists and turns of the eflornithine story illustrate but one of the many ways in which society's decision to allow the research and development 
agenda for new drugs to be dominated by commercial considerations can produce morally perverse consequences.

In sum, the critics of corporate funding argue that if biomedical research continues to be absorbed within the profit seeking ethos of the marketplace, the norms of commerce may swamp both the traditional norms of science and the best interests of the wider community; the disinterested pursuit of knowledge may give way to the entrepreneurial pursuit of financial self interest, and universities and hospitals may forfeit the public trust without which they cannot function. This is a serious charge sheet, and there is a growing body of evidence to support the conclusion that the traditional norms of science ought to be placed, forthwith, on the Endangered Species List. What follows is a sampling of that evidence.

\section{CORPORATE FINANCING OF MEDICAL RESEARCH IN NORTH AMERICA: A BRIEF OVERVIEW}

As the United States emerged from the second world war, the funding of scientific research became a top national priority. A report prepared for President Harry Truman, by Vannevar Bush, director of the wartime Office of Scientific Research and Development, argued that the advancement of scientific knowledge through massive spending on research was necessary for America's health, prosperity, and security and that, in consequence, government funding of scientific research ought to enjoy the highest priority. ${ }^{25}$

The fifties and sixties in America were a golden age for government funding of basic scientific research, with most funds dispersed through the National Institutes of Health (NIH). Scientists enjoyed a high degree of research independence and were comparatively free from commercial pressure to produce short term results. During this period, less than five per cent of university research funding came from private industry. Thus, direct interaction between academic scientists, on the one hand, and for profit corporations, on the other, was rather limited. By the late seventies, however, academic science came to be viewed by both industry and government as a potentially powerful commercial weapon in an increasingly competitive world economy. Laws were passed to strengthen intellectual property rights. With the passage of the Bayh-Dole Act (1980), which permitted American universities and university researchers to patent discoveries resulting from federally funded research, the academic world moved very rapidly toward the world of business. That same year, 1980, also saw some important judicial decisions supporting patent protection for bioengineered molecules. ${ }^{26}$ In the fifteen year period between 1974 and the early 1990s, corporate support for academic biomedical research increased from less than five million dollars to hundreds of millions. ${ }^{27}$ By the beginning of the new millennium, for profit companies were providing financial support for 70 per cent of clinical drug trials. ${ }^{28}$

So called "strategic alliances" between universities and the pharmaceutical industry flourished, in part because of the perception that federal research funds were decliningwhich turned out to be true in Canada, though untrue in the US. The corollary fear was that lost federal funds could only be replaced by the private sector. In addition, as American scholar Sheldon Krimsky notes, there were also technological developments that helped to promote such partnerships: "... I]n biosciences you can now go from the lab to commerce very quickly because of gene splicing" ${ }^{\prime 29}$ This technological development in the life sciences, sometimes referred to as "the genomics revolution", had the effect of blurring the distinction between "pure" and "applied" research.

For these reasons, large scale "scientific entrepreneurship" moved, almost in one fell swoop, from being an oxymoron to becoming the prevailing norm on university campuses across America. The pharmaceutical industry became the major source of grants for researchers carrying out clinical trials and a major financial contributor to medical schools and universities, via donations of capital and equipment. Even medical journal editors had reason to feel gratitude for the generosity of the pharmaceutical industry, which began to provide significant financial subsidies via the purchase of advertisements and special supplements to the main journal. Scientific articles appearing in these corporate financed sections of academic medical journals, although signed by otherwise reputable researchers, would often be ghostwritten by company employees. No good data are currently available about the percentage of articles, whether in the peer reviewed sections of journals or in non-peer reviewed supplements, which are ghostwritten. Understandably, neither the ghostwriters, who are paid between $\$ 10000$ and \$20000 per article, nor the authors who allow their names to appear on these articles, are anxious to have their identities revealed. The practice of ghostwriting appears to be not uncommon, according to an investigative report done for the CBC TV programme Marketplace (Marketplace, CBC TV, 25 Mar 03). "Authors" would often not even have access to the raw data on which their "findings" were based. Unlike the rest of the journal's content, such supplementary articles would not be peer reviewed (Healy D, unpublished ms: Shaping the intimate influences on the experience of everyday nerves). The industry hopes, presumably, that by placing their supplements within the covers of prestigious journals, these industry funded studies will parasitically acquire scientific legitimacy. Status by association could then be exploited by drug company salespeople ("reps") when marketing their products to the large number of "docs" whose busy clinical practices leave them short of time to check on the bona fides of published studies.

The story in Canada follows a similar trajectory, though with a time lag of about ten years. Sometime around the late eighties, the Canadian federal government came to view multinational drug companies as a major vehicle for promoting economic growth. Despite consumer fears of rising drug costs, patent protection was extended. The pharmaceutical industry promised, as its quid pro quo for this extension, that it would increase its spending on Canadian drug research. By the 1990s, despite fears of government retrenchment, American government spending on drug research was actually doubling. At the same time, Canadian governments decided to battle rising national debt and deficits by cutting and freezing grants for medical research. Canadian researchers were thus caught in a squeeze between (a) the rising costs of medical research and (b) their stagnant or shrinking research grants from government. Salvation, of a kind, was provided by industrial sponsorship.

Canadian biomedical researchers shared the excitement of their American colleagues at the prospect of participating in major scientific discoveries. Canada's leading research universities and their affiliated teaching hospitals shared with their American counterparts an aspiration toward research excellence. In order, however, to achieve national or, better still, international research standing, universities and research hospital required massive new funds, funds sufficient both to build and equip first rate laboratories and to attract and keep top notch researchers. Thus, since Canadian governments, federal and provincial, seemed unable or unwilling to provide needed research funding, universities and hospitals felt themselves compelled to go, virtually cap in hand, to the pharmaceutical industry.

In these circumstances, it is not surprising that leading universities and teaching hospitals made a conscious decision to devote the time and energy necessary to build and sustain 
the good will of drug company executives. The case for diligently pursuing corporate sponsorships is made vividly by Michael Strofolino, President of Sick Kids Hospital at the height of the Olivieri scandal: "Our goal is to be the best hospital in the world, to be number 1 . How do we do it? Do we close down commercialism? Do you think the federal government is going to give us the money? Do you think we're going to get scientists to come up to Canada in an environment like that?" ${ }^{\prime 1}$ For Strofolino, but also for many other hospital and university presidents and deans, commercialising university research by marketing universities to wealthy corporations was the best way, perhaps the only realistic way, to obtain the hundreds of millions of dollars needed to achieve research excellence. This commercial "imperative" has grown, if anything, more pressing over time.

Hence the current popularity of what have come to be called university/industry "partnerships". As suggested above, the beneficiaries are not just biomedical researchers, casting about for research funding. Cash starved universities and hospitals themselves stand to make considerable fortunes by cultivating joint ventures with private industry. Corporate funding has become crucial to the business plans of many North American universities. It has provided universities and their affiliated research hospitals with the resources they need to strive for excellence. When new drugs are discovered and patented the university can then collect its share of what will sometimes prove to be a veritable "gold mine". Johns Hopkins University again provides us with some prime examples:

\section{Hopkins ... permitted physicians to do human testing of tiny Magnetic Resonance Imaging devices that they had invented-instruments being developed by a company that the doctors and Hopkins partly own. A Hopkins neurologist recently tested a drug that could earn millions for Hopkins, some of its leading scientists and a company closely tied to both.}

For this reason, university presidents and deans are often chosen, at least partly, on the basis of their attractiveness to potential corporate donors. The national and international league table of universities assigns its top places to those most successful at raising the vast sums of private money necessary to hire the best researchers and provide them with the best laboratories, the best equipment, and the most doctoral and postdoctoral students, in order to produce the best and most profitable research.

These developments, increasingly prevalent at North American research universities, have led critics to accuse the entrepreneurial university of institutional conflict of interest. One study reports that approximately two thirds of academic institutions hold equity in "start up" businesses that sponsor research performed at their university. ${ }^{30}$ When academic institutions have become businesses, seeking to commercialise and profit from their inhouse research discoveries, can the public still look to them as sources of objective scholarly information $?^{31}$

The death of eighteen year old Jesse Gelsinger, who had altruistically volunteered to participate as a research subject in an industry sponsored gene therapy trial, focused attention on the issue of whether individual and institutional financial conflicts of interest were responsible for undermining the protection of research subjects. ${ }^{32}$ The US government's Food and Drug Administration (FDA) has charged the clinical researchers involved in the Gelsinger case with inadequately informing him of the risks entailed by this trial and also with a conflict between their financial interest in a gene therapy technology company and their duty to protect the safety of research subjects. The most troubling question raised by the Gelsinger case, one which has not yet been properly answered, is: how can universities and hospitals assure the public that they will rigorously and impartially oversee the ethics of research carried out by their scientists when both the researchers and the institutions have acquired a significant financial stake in the outcome of the research? Answers to this question will be explored below, under the heading of "conflict of interest".

\section{THE ETHICS AND PRAGMATICS OF INDUSTRY SUPPORT FOR UNIVERSITY BIOMEDICAL RESEARCH}

One of the most influential studies of how researchers' objectivity might be compromised by drug industry sponsorship appeared in The New England Journal of Medicine, in January of $1998 .^{33}$ Stelfox and colleagues set out to examine published articles on the safety of calcium channel antagonists. Their goal was to answer the question: to what extent does industry support of medical research influence the research findings of investigators? For the purposes of this study, Stelfox divided authors according to their relationships with pharmaceutical companies and then, independently, classified their research findings on the safety issue as "supportive", "critical", or "neutral". The conclusion reached by Stelfox et al must be of serious concern to every supporter of industry university partnerships: "Our results demonstrate a strong association between authors' published positions on the safety of calcium channel antagonists and their financial relationships with pharmaceutical manufacturers." ${ }^{\prime 33}$

It may be worth spelling out just how influential drug company sponsorship appears to have been: "Ninety six per cent of supportive authors had financial relationships with the manufacturers of calcium channel antagonists, as compared with 60 per cent of the neutral authors and 37 per cent of the critical authors." ${ }^{\prime 33}$ A caveat is required here. The Stelfox study needs be interpreted with care. Were authors first funded by companies making calcium channel blockers, after which they wrote favourably about the product, or did they first write favourably about the product and only then receive financial support from the companies? Since the Stelfox authors were unable to determine the time line, this question cannot be answered conclusively. Interestingly, even researchers who had financial ties with manufacturers of competing products were significantly less critical of the drugs being tested than authors who had no ties to industry. In other words, scientists who are funded by the pharmaceutical industry produce studies which tend to be more favourable to new drugs than those whose funding is industry independent even when the new drug being tested is produced by a rival company.

In a more recent study, Bekelman and colleagues have attempted a comprehensive synthesis of evidence relating to biomedical conflicts of interest. ${ }^{34}$ According to their data, over a period of roughly two decades (January 1980 to October 2002), approximately one fourth of investigators were found to have industry affiliations, and roughly two thirds of academic institutions were found to hold equity in start ups that sponsor research performed at the same institution. By combining data from articles examining 1140 studies, Bekelman found that "industry sponsored studies were significantly more likely to reach conclusions that were favourable to the sponsor than were non-industry studies" ${ }^{\prime 34}$ Thus, Bekelman's findings are consistent with those of Stelfox. The Bekelman study also found that industry sponsorship was associated with restrictions on publication and data sharing. Bekelman et al conclude: "Financial relationships among industry, scientific investigators and academic institutions are widespread. Conflicts of interest 
arising from these ties can influence biomedical research in important ways." ${ }^{34}$

Lexchin and colleagues have also done a comprehensive meta-analysis of what is currently known about the alleged tendency of drug company sponsorship to produce biased research results. ${ }^{35}$ They conclude that "there is some kind of systematic bias to the outcome of published research funded by the pharmaceutical industry":

Research sponsored by the drug industry was more likely to produce results favouring the product made by the company sponsoring the research than studies funded by other sources. The results apply across a wide range of disease states, drugs and drug classes, over at least two decades and regardless of the type of research being assessed-pharmacoeconomic studies, clinical trials, or meta-analyses of clinical trials. ${ }^{35}$

Although it seems intuitively obvious that "he who pays the piper calls the tune", there are several different and competing hypotheses, each of which may explain why it is the case that when a pharmaceutical company pays for the clinical trial of its new drug, the results are more likely to be favourable to that drug than when the funding is industry independent. (1) It is possible that the pharmaceutical companies are highly skilful at picking "winner" drugs; or (2) industry sponsored trials might be of low quality (thereby exaggerating treatment benefits); or (3) drug company sponsored research might produced biased results (whether consciously or subconsciously) because it chooses inappropriate comparator agents, or, finally, (4) publication bias might be an important factor.

Lexchin et al argue that there is no empirical evidence to support the first two hypotheses. Bekelman agrees, citing four studies, each of which demonstrates empirically that industry preferentially supports trial designs that favour the new drug being tested (thereby refuting the first hypothesis). ${ }^{346}$ The second hypothesis blends into the third to the extent that the allegedly poor quality of the studies is attributable to the use of inappropriate control therapies. The third hypothesis is potentially important, Lexchin and Bekelman both acknowledge, but Lexchin argues that it requires further investigation. By contrast, the hypothesis of publication bias seems well supported, both by a number of studies done specifically on the issue of publication bias, and also by a number of high profile cases-for example, Apotex/ Olivieri and Knoll; Boots Pharmaceutical/Betty Dong-in which drug companies have attempted to prevent researchers from publishing studies unfavourable to their products. See also a paper by P A Rochon, et al, ${ }^{37}$ and one by E Shenk. ${ }^{38}$

The phrase "publication bias" seems to originate with a 1980 JAMA article by Smith. ${ }^{39}$ It is employed to describe a "tendency on the parts of investigators, reviewers or editors to submit or accept manuscripts for publication based upon the direction or strength of the study findings". ${ }^{40}$ There is now a considerable body of evidence in support of the hypothesis that when the results of a clinical trial are unfavourable to the new drug being tested, the researchers often decide not to publish (in order not to alienate the good will of their sponsors), or the company may decide that the researchers will not be allowed to publish (as happened in the Olivieri/Apotex case), or journal editors may decide they are uninterested in publishing studies which have produced negative results. Another caveat. Publication bias certainly exists, but there is as yet, no published research (as distinguished from anecdotal reports) which distinguishes carefully among the possible causes of the bias. What can be said with confidence, however, is that when publication bias occurs, the effect is to deprive clinicians and patients alike of some part of the materially relevant evidence needed for them to make good treatment decisions.

Publication bias is sometimes referred to, colloquially, as "the file drawer effect". Suppose that there are twenty studies done of some new drug; and suppose that of those twenty studies, six are positive and fourteen are negative. Suppose, further, that as a direct or indirect result of company influence, twelve of the negative studies are not published (that is, they are banished to the file drawer), while every positive study is published, celebrated even. Those physicians who then attempt conscientiously to review the literature would find six positive but only two negative studies. (I owe this way of explaining the issue to Dr Paul Ranalli.) The new drug would be hailed as a medical breakthrough and would rapidly become part of standard therapy. This is not science, however, so much as marketing through censorship or self censorship. If the much touted movement towards "evidence based medicine" is to mean anything, then physicians need unbiased data on the clinical effectiveness, toxicity, convenience, and cost of new drugs compared with available alternatives. ${ }^{41}$ Because of the phenomenon of publication bias, what passes for good scientific evidence may be simply a mirage.

The findings of Bekelman and Lexchin clearly call into question the integrity of company funded research. ${ }^{34}{ }^{35}$ Since company funded research has become preponderant, in both Canada and the US, the clear implication is that the integrity problem is both systemic and serious. Evidence for this claim is provided by both Statistics Canada and the Office of Technology Assessment in the USA. ${ }^{42}{ }^{43}$

As noted above, when clinicians consult a drug study to help them in their treatment decisions, they are generally seeking objective information about the comparative effectiveness, toxicity, and cost of the new drug compared to available alternatives. Bero and Rennie clearly summarise some of the reasons why clinicians often do not find such vital information in the current literature:

Many examples of published drug studies fail to fill this need. Clinicians too often see studies that favourably compare the new drug with a second rate alternative, studies that compare doses of drugs that favour the new product, studies that test the new drug on the wrong subjects, studies that are too small to test hypotheses, and studies with unsupported conclusions. ${ }^{41}$ still:

Bleak as this picture may be, reality is sometimes bleaker

\section{Even well designed studies can be poorly conducted, and biases that favour the sponsor's product can be introduced by protocol violations, failure to keep proper records, or failure to submit accurate data to the journal for publication. ${ }^{41}$}

This last mentioned danger is illustrated by the way in which drug manufacturer Pharmacia was able to elicit a favourable editorial in JAMA for its blockbuster arthritis drug Celebrex, in the summer of 2000.

Celebrex was tested over a period of twelve months in a Pharmacia sponsored study. The study showed, based on data from the first six months of the trial, that this new drug was associated with lower rates of stomach and intestinal ulcers than two older and much less expensive drugs. To his subsequent chagrin, arthritis expert M Michael Wolfe did not discover until after his favourable appraisal of Celebrex was published in JAMA that the company possessed an additional 
six months of data. When the full year's data-to which Wolfe was not given timely access-were taken into account, the Celebrex advantage at the six month point had virtually disappeared. Dr Wolfe was, understandably, furious. JAMA's editor, Catherine DeAngelis lamented: "I am disheartened to hear that they had those data at the time they submitted [the manuscript] to us." 44

All of the JAMA Celebrex study's authors were either employees of the sponsoring drug company, Pharmacia, or paid consultants of the company. More worrying, at least for those who still believe that the public can reliably trust to the integrity of university researchers, is the fact that half of the study's 16 authors were medical faculty at eight different medical schools.

With its trust in the integrity of the biomedical science community somewhat dented, if not entirely shattered, JAMA now requires a statement, signed by an author who is not employed by the sponsoring company, in which responsibility is taken "for the integrity of the data and the accuracy of the data analyses" ${ }^{44}$ Although Pharmacia continues to claim that Celebrex has a superior safety profile, the US government Food and Drug Administration's arthritis advisory committee concluded, based on the full year's data, that Celebrex offers no proven safety advantage, compared to the two older drugs, in reducing the risk of ulcer complications.

Bero and Rennie conclude that the pharmaceutical industry must take some responsibility for the poor quality of published drug studies, but their exhortation to the industry to show educational leadership is somewhat undercut by their own observation that "the pharmaceutical industry has little incentive to conduct and publish the type of drug study that the practising clinician needs most". ${ }^{41}$ The same conclusion is reached by P A Dieppe, et al. ${ }^{45}$ One may be forgiven for doubting whether manufacturers of new and expensive drugs would often be keen to fund studies the purpose of which is to determine whether inexpensive, off patent drugs could replace profitable single source products. All the more reason why the public should not hold its breath waiting for the pharmaceutical industry to fund studies into the curative powers of vitamins, broccoli, or regular exercise, since none of these treatment modalities lends itself as readily as prescription drugs to commercial exploitation. In other words, despite what Bero and Rennie have to say, the pharmaceutical industry is not likely to adopt with enthusiasm any educational role which threatens to weaken its bottom line. If the public needs good quality drug studiesand clearly it does-then the public may have to reconsider whether it can afford to rely on industry funding of biomedical research.

\section{BIOMEDICAL CONFLICTS OF INTEREST}

A proper understanding of "conflict of interest" is essential for a clear understanding of why corporate sponsorship of university research is ethically troubling. Denis Thompson's formulation, which has become more or less standard in the biomedical literature, defines a conflict of interest as "a set of conditions in which professional judgment concerning a primary interest ( such as a patient's welfare or the validity of research) tends to be unduly influenced by a secondary interest (such as financial gain)" ${ }^{46}$ Since Thompson's use of the term "interest" to describe a physician's duty to her patient is both idiosyncratic and potentially misleading, the following definition seems preferable:

A person is in a conflict of interest situation if she is in a relationship with another in which she has a moral obligation to exercise her judgment in that other's service and, at the same time, she has an interest tending to interfere with the proper exercise of judgment in that relationship. ${ }^{47}$

"Judgment" refers to intelligent activity requiring more than mechanical rule following. "Interest" refers to personal financial benefit or family interest or any special influence or loyalty which could undermine the performance of one's duty to exercise one's judgment objectively.

Since the concept of conflict of interest is beset by a certain amount of confusion, it may be helpful to illustrate its application within the field of medical research. As noted earlier, every doctor is bound by oath "to put the life and health of my patient first". So, when physicians engaged in medical research accept drug company funding or consulting fees, or gifts or free travel, the acceptance of such benefits, and the hope for more in the future, makes them beholden to the company and thereby puts them in a conflict of interest situation. Physicians have a fiduciary duty or obligation to their patients/research subjects-a duty to put the patients' interest first-but they now have an interest, a financial and career "vested interest" in the success of the new drug being tested.

It would, of course, be naïve to deny that many conflicts of interest are not financial. Thus, a researcher's duty to exercise his judgment on behalf of his patients/subjects could be biased by considerations such as the desire for enhanced status, winning the race against scientific competitors, promotion through the academic hierarchy, and so on. It is likely not possible to eliminate completely all conflicts of interest. Nevertheless, wherever possible, society ought to strive to eliminate or, at least, to minimise, conflicts of interest. Even when there is no formal contractual obligation between medical researchers and their industrial sponsors, feelings of being beholden to the company have a tendency to influence professional judgment. By selling their good will to the companies, in return for personal benefits, researchers are guilty of betraying the trust of their subjects.

Thus, a medical researcher is in a conflict of interest situation when she has an ethical obligation to put the interests of her patients first, but she also has a private interest (pleasing a drug company sponsor, let us say, in order that grants and consulting fees continue) that has a tendency to interfere with the proper exercise of her judgment on behalf of her patient/research subject. If a researcher stands to gain monetary and/or career success by demonstrating the virtues of a new drug, and stands to lose research funding and perhaps her job if she finds that the new drug is unsafe or comparatively ineffective, then she is in a conflict of interest situation. This is true even if she does not succumb to temptation. That is, even if the researcher successfully preserves the objectivity of her judgment, it nevertheless remains true that she is in a conflict of interest situation-simply because of the presence of powerful financial and career incentives with a tendency to bias research. Carl Elliott offers a helpful analogy:

If a policeman takes money to overlook a speeding violation and then writes the ticket anyway, he has still accepted a bribe, even if he has not been influenced by it. The point is that certain people in whom public trust is placed must not have a financial interest in violating the duties carried by their institutional role. In this respect, at least, they must be financially disinterested. What is more, they must be seen to be disinterested; otherwise, the institution they represent risks falling apart. ${ }^{48}$

Elliott is here writing about the impropriety of ethicists accepting financial and other benefits for consulting work 
they do for the pharmaceutical industry, but his point applies with at least as much force when we turn to the issue of clinical researchers accepting financial benefits from industry. This point is explored in more detail below, under the heading of "What is to be done?"

Some defenders of university/industry partnerships may dismiss this application of Elliott's argument by analogy. They could point out, quite correctly, that to bribe a policeman is a criminal act, whereas a contract to accept industry funding is not illegal. When a university researcher accepts grants from industry, what have to be assessed are the terms of the contract and the understandings, explicit and implicit, between the parties. If a researcher accepts the funding and treats it as an unconditional grant-not different in kind from a government grant - then there will be no bad consequences.

To this argument, critics of university/industry partnerships are likely to respond that the risk of being blacklisted in the fierce competition for future grants could easily influence at least some researchers to tickle their research design or massage their data in order to produce pleasing (to their sponsors) results. As we have seen, there is mounting evidence in the literature indicating that this research bias seems to be occurring with considerable frequency. Of course, many companies will be deterred from egregious forms of cajolery and of bullying against biomedical researchers by the fear of critical media attention. However, a few dramatic cases, in which researchers find their careers in ruins because their findings do not enhance their sponsors' bottom line, might be sufficient, as the French say, pour encourager les autres. Moreover, even without explicit threats, companies have subtler ways of communicating to the biomedical research community what sort of performance is likely to enhance future opportunities for collaboration.

This is not to say that financial gain, career success, and personal prestige are in and of themselves unworthy goals. The salient point is, rather, that by putting researchers in a conflict of interest situation industry sponsorship can threaten the objectivity and reliability of research. A physician/researcher who puts herself in a conflict of interest situation leaves open the possibility that her vested interest will potentially exert an inappropriate influence on the design of the research or the collection, analysis, and disclosure of data. The studies and metastudies cited in earlier sections of this paper suggest that drug company sponsorship of research has a marked tendency to produce the kind of bias that undermines professional integrity.

If a biomedical researcher deliberately sets out to "lose" adverse data about a sponsor's drug, or consciously chooses a comparator which will artificially enhance the apparent effectiveness of the new drug, then he or she would be guilty of outright fraud. The evidence pertaining to medical fraud suggests, however, that only a small minority of scientists are corrupt in this way. The majority are honest. Honest, but often (unconsciously) biased in favour of the products of the sponsoring company. (Or generally biased in favour of new drugs, even when they are the products of a competitor company). In other words, conflicts of interest have the potential to produce dishonesty, but this may be a less common problem than their tendency to undermine the integrity of research in the subtler ways discussed above. See also the paper by Avorn J, et al. ${ }^{49}$ This paper shows that doctors are probably unconsciously influenced by pharmaceutical promotion.

It is possible, as suggested earlier, to design a study that compares a new drug not to the best available alternative, but to a placebo, or to a drug already proven to be ineffective. In this way, new drugs that should not succeed commercially, because they are less good than the best already available, may nevertheless-through heavy marketing and good salesmanship to doctors-become a commercial success. The Patented Medicine Prices Review Board reports that a mere six per cent of new drugs can be classified as "substantial improvements" over already existing treatments; the board's annual reports for 1998-2001 are cited by $\mathrm{P}$ Baird. $^{50}$ It seems clear, therefore, that the regulatory environment badly needs to be reinforced. Licensing bodies could insist-for example, on robust designs with adequate oversight. If one inquires, however, why university and hospital research boards and government regulatory agencies are not providing adequate oversight, the answer may turn out to be that these regulatory bodies have been "captured" by the very industries they are mandated to oversee. ${ }^{3151}$

Researchers typically do not realise that their professional commitment to research integrity and patient safety can be compromised by their self interested pursuit of career success or financial profit or prestige. Many become indignant when this suggestion is put to them. Although I have lectured widely in North America and England on the threat to scientific objectivity posed by the financial and career benefits which the pharmaceutical industry bestows upon medical researchers, no researcher has ever admitted to me that the receipt of substantial grants, fancy trips, honoraria, consulting fees, royalty payments, or corporate share holdings has biased his or her scientific judgment. When it comes to research design or data collection and analysis, each researcher sees (or at least claims to see) his/her scientific objectivity as incorruptible. It should be mentioned that bioethicists-who are latecomers to the drug industry gravy train-seem equally confident that their judgment is not prejudicially affected by the acceptance of money and other benefits from industry (personal observation by the author).

Similarly, medical students seldom admit that the drug companies, which have graciously supplied them with free beer and pizza, or textbooks, have at the same time purchased their good will. Doctors seldom admit that their clinical judgment has been influenced by the acceptance of lavish dinners, free laptop computers, or skiing holidays to Vail, Colorado. Top university and hospital officials strenuously deny any suggestion that the receipt of donations or research funds from drug companies has skewed in any way their performance of their duties. Nor do they believe that a university's ownership of patents in new drugs being tested at the university could potentially undermine the rigour with which the university polices the integrity of the research carried out under its aegis.

"I can't be bought for ... (fill in the blank: research funding, major donations, consulting fee, royalties, Caribbean holiday, laptop computer, fancy dinner, free pizza, whatever)". Employing these or similar words, members of the biomedical research community, physicians, medical students, bioethicists, and university and hospital officials, confidently affirm that there is no harm done-certainly not to their own integrity-by the acceptance of drug company beneficences. Those who perceive such protestations as instances of hypocrisy or self deception are generally met with disbelief:

... few doctors accept that they themselves have been
corrupted. Most doctors believe that they are quite
untouched by the seductive ways of industry marketing
men; that they are uninfluenced by the promotional
propaganda they receive; that they can enjoy a com-
pany's "generosity" in the form of gifts and hospitality
without prescribing its products. The degree to which the
profession, mainly composed of honourable and decent
people, can practise such self deceit is quite extraordinary. 


\section{No drug company gives away its shareholders' money in an act of disinterested generosity. ${ }^{52}$}

These words were aimed at clinicians, but they could just as easily have been directed towards clinical researchers. The self righteousness with which biomedical researchers deny that they might themselves have been biased by acceptance of drug company money encourages the surmise that industry may understand something fundamental about human nature, something which the medical and biomedical research communities, in their naiveté, have somehow overlooked.

What the drug companies understand is that much of social life is based on reciprocity. The need to return benefit for benefit, kindness for kindness, and favour for favour is a basic motivator in virtually every human society, past or present. It behoves us, therefore, to consider that every dollar of the hundreds of millions of dollars which the companies invest in grants and gifts to researchers, hospitals and universities, doctors, and medical students is viewed by the companies as an important part of their corporate strategy. This is not meant to deny that industry has other motivations as well when it funds university research. "Genuine discovery", leading to worthwhile products, is surely one of the motives which shapes the behaviour of pharmaceutical executives. Sophisticated industry officials understand that good science can often be highly profitable and that, in the long run, bad science is likely to be exposed. Nevertheless, in the lean mean competitive world of the global marketplace, the future of a company's stock, like the career progress of its executives, will often depend on a rapidly rising "bottom line". Short term considerations, it seems all too clear, can sometimes exert considerable pressure on companies. It would be surprising if some of this pressure were not transmitted, directly or indirectly, to the scientists whose research the companies are funding.

To put this point in another way, whether intended or not, every grant and gift from a pharmaceutical company to scientists or to their university or hospital comes with strings attached. Strings that are sometimes as heavy and oppressive as lead chains.

It is also important to note that most studies in the biomedical literature are concerned with conflicts of interest at the micro level, that is, at the level of individual researchers and their published (or deliberately not published) results. A similar phenomenon arises, however, at the macro level. When institutions, such as universities and hospitals, compete for drug company research sponsorships and donations, and when such public institutions believe, perhaps correctly, that without industry money they cannot flourish, it becomes increasingly difficult for them to guard and protect traditional institutional values. In the pursuit of scientific excellence through industry funding and donations universities and their teaching hospitals can find themselves unwittingly allied with wealthy companies against their own researchers (and their own patients).

University administrators, including especially presidents and medical faculty deans, have a professional obligation to ensure that the research carried on within their institutions respects the core values of academic freedom, research integrity, and patient safety. There is a growing body of data, however, suggesting that institutional integrity is no less easily eroded than individual integrity. As Carl Elliott observes:

Corporate money is so crucial to the way that university medical centres are funded today that no threat or offers need actually be made in order for a company to exert its

\section{influence. The mere presence of corporate money is enough. ${ }^{48}$}

Consider again the University of Toronto's behaviour in the Olivieri/Apotex and Healy/Eli Lilly cases. As we have seen, in the Olivieri/Apotex case there were legal threats made against a university researcher, Olivieri, in an effort to prevent her disclosing adverse information about the company's drug and, simultaneously, there were negotiations for a very large company gift from Apotex to the university. In the Healy/Eli Lilly case, by contrast, there is no suggestion that Healy was put on legal notice by the company whose drug he criticised, and the corporate financial donation (from Eli Lilly to CAMH) had already taken place. Nevertheless, the story played out in very similar fashion in both cases. This suggests that the presence or absence of explicit company threats- to cut off research funds, let us say-is not of great importance. When the university becomes a business, its top officials are virtually required to adopt commercial values as an adjunct to their academic values. Institutional conflict of interest par excellence.

\section{WHAT IS TO BE DONE? THE REFORMIST PACKAGE}

Not everyone agrees that the commercialisation of university research creates an ethical minefield for academic science. Certainly, spokespersons for industry downplay the potential for conflicts of interest. Instead, they tend to stress the many ways in which industrial sponsorship of university research has promoted the advancement of science, created beneficial new drugs, developed a market for them, and thereby made possible both corporate profits and the flourishing of scientific creativity. These claims are not without merit. Many members of the biomedical research community would endorse them with enthusiasm.

As recently as 1997, an editorial commentary in Nature denies outright the view that industrial sponsorship of research has resulted in serious risks of fraud, deception, or bias in presentation of data. The editor then proceeds to reject the call from other journal editors for mandatory disclosure of researchers' personal financial interests. ${ }^{53}$ In the same vein, but a few years earlier, Kenneth Rothman, editor of the journal Epidemiology, writing in JAMA, disparaged the proposal for mandatory disclosure by researchers of their industrial ties. Rothman goes so far as to tag such proposals with the pejorative label "the new McCarthyism in science" ${ }^{.54}$

In the 1990s, at the time these antidisclosure editorials were appearing in Nature and JAMA, only a few American scientific journals had instituted a policy of mandatory conflict of interest disclosure. By the autumn of 2001, however, growing awareness of the dangers which widespread industrial sponsorship posed to scientific objectivity led editors of many of the world's leading general medical journals to sound the alarm and jointly to strengthen their ethics requirements for authors publishing in their journals. ${ }^{55}$ Henceforth, research published in journals such as the New England Journal of Medicine, the Lancet, the Journal of the American Medical Association, and the Canadian Medical Association Journal had to meet a newly promulgated set of ethical requirements. ${ }^{56}$ Under these revised rules, authors are routinely compelled to disclose details of their own and their sponsor's role in the study. Moreover, the lead ("responsible $^{\prime \prime}$ ) author is required to sign a statement indicating that he/she accepts full responsibility for the conduct of the trial, had full access to the data, and controlled the decision to publish. A caveat in the editorial explains, however, that not every journal editor who signed this statement will require this particular provision. The objective of these requirements is to ensure that commercial sponsors are not in a position to impose "any impediment, direct or indirect, on 
the publication of the study's full results, including data perceived to be detrimental to the product". ${ }^{56}$ This newly reinforced code of publication ethics, the editors tell us, is intended to safeguard "the hallmarks of scholarly independence and, ultimately, academic freedom". ${ }^{56}$

It should also be noted that even Nature appears to be having second thoughts. That journal's hostility to "McCarthy-ite" scientists has been replaced, a mere four years later, by a recognition that "t] here are circumstances in which selection of evidence, interpretation of results or emphasis of presentation might be inadvertently or even deliberately biased by a researcher's other interests". ${ }^{57}$ The current editor of Nature, Philip Campbell, continues to deny that "commercial interests of researchers are likely to lead to a lack of research integrity", but now concedes that "the best way to maintain readers' trust ... is through a policy of transparency".57 A 2002 article by F Van Kolfschooten, also in Nature, argues that disclosure is fast becoming the norm with respect to conflicts of interest in scientific research. ${ }^{58}$

In short, the view that disclosure is the key to dealing with biomedical conflicts of interest seems to be gaining wide acceptance within the biomedical research community, even among those who were previously doubtful. Especially noteworthy is the endorsement by Stelfox et al in their seminal 1998 NEJM article on calcium channel antagonists, discussed above: "Physicians and researchers simply need to disclose their financial relationships with pharmaceutical manufacturers appropriately". ${ }^{33}$ Full disclosure will do the trick, they insist, because "w]e believe that the authors we surveyed expressed their own opinions and were not influenced by financial relationships with pharmaceutical manufacturers". Thus, according to Stelfox, the real problem is one of public relations: "I]t is our opinion that scientific authors are naive about public perceptions concerning such relationships [of industry sponsorship]". ${ }^{33}$ That is to say, the public would be upset were it to discover that scientific authors had undisclosed relationships with the sponsor whose products they were touting. To affirm the integrity of the medical profession and to maintain public confidence, according to Stelfox, it is necessary (and sufficient) that there be full disclosure of the relationships between physicians and pharmaceutical manufacturers.

Pause for a moment to consider the extraordinary claim by Stelfox and his colleagues, quoted above, that researchers (at least those they surveyed) are not influenced (even to a slight degree?) by either research funding from or their financial relationships with the pharmaceutical industry. Ironically, the Stelfox claim of non-influence comes immediately after he and his colleagues have presented evidence of a dramatic association between industry sponsorship and pro-industry results. Admittedly, since we have not yet got research to demonstrate conclusively which came first, the favourable articles or the industry funding, a certain degree of agnosticism on the question of influence is warranted. What is clearly not warranted, however, is belief in the non-influence hypothesis. Moreover, even if it turns out that in some cases the positive results came first and the industry funding then followed, such a practice, if widespread, would be a very strong inducement for researchers to design and carry out investigations likely to have industry favourable results. In short, the refusal by Stelfox et al even to entertain the possibility that industry funding has a tendency to bias research seems to be a matter of blind faith.

If Stelfox et al are mistaken in their unsupported belief, as their own data suggests they might be, then the threat to research integrity may be more than an optical illusion, and the solution they propose-full disclosure-may be inadequate to the twin tasks of ensuring research integrity and safeguarding the public's trust in the reliability of biomedical research.

Other scholars, more seriously concerned than Stelfox and Nature about the corrosive effects of industry sponsorship on university research, have contributed additional reform proposals, all with a view to shoring up research integrity and public confidence. As mentioned above, the International Committee of Medical Journal Editors [ICMJE] requires, in addition to rules about disclosure of financial ties, that authors participate in the trial design, have access to data, and control publication.

Even these measures, however, seem insufficient to deal with the problem of "publication bias". Some argue that the most effective measure would be prospective registration of all trials, perhaps even all preliminary research studies. Dickersin notes that such registers already exist for several research areas $^{40}$ and contends sensibly that "if treatment decisions are based on the published literature, then the literature must include all available data that is of acceptable quality" ${ }^{40}$ Perhaps it is time for the ICMJE to accept their own partial responsibility for a failure to deal with the problem of publication bias, and commit their journals to an editorial policy whereby the decision to publish will be based "on issues of quality and logical reasoning by the authors and not the direction and strength of study results".$^{40}$ In other words, arguably, journal editors have a duty, in the interest of promoting research integrity, to ensure that good quality studies which happen to reach negative conclusions about a new drug are not consigned, along with their authors, to the dustbin of history. Without some such reform, researchers will continue to labour under a serious conflict of interest, but the personal interests tending to bias their results will include career advancement (via publication) rather than simply vested financial interests, which have been the main focus of the discussion so far.

Bero and Rennie suggest additional reforms which would have, they believe, the effect of improving the quality of drug studies (Bero LA, et al, ${ }^{41}$ pp 209-37). They recommend, among other things, that pharmaceutical companies should support "investigator initiated research that focuses on questions that are shaped by broad scientific interests rather than narrow commercial interests" (Bero LA, et al, ${ }^{41}$ pp 20937). Indeed, just the kind of research that used to be done much more commonly a few decades ago, in the era before university/industry partnerships. They recommend that a "user fee" be imposed on drug companies to fund studies on comparative effectiveness, together with a new requirement (in order for companies to obtain government drug approval) that companies provide data comparing new drugs with available alternatives for effectiveness and cost. Their "wish list" also includes a stipulation that drug companies leave the planning and monitoring of the research design completely [my emphasis] to the funded investigators, and that they (the companies) not be involved in the presentation of the data-measures intended to promote balance and to minimise skewed interpretation (Bero L A, et al, ${ }^{41}$ pp 209-37).

\section{THINKING THE UNTHINKABLE: THE SEQUESTRATION THESIS}

The above listed reform proposals, if rigorously implemented, would almost certainly improve the quality and scientific integrity of published biomedical research. Unfortunately, such evidence as we have suggests that the reformist package is not currently being implemented to an extent that even begins to approach what is called for in present circumstances.

A recently published (2002) national survey shows that "academic institutions routinely participate in clinical research that does not adhere to ICMJE standards of 
accountability, access to data, and control of publication" ${ }^{59}$ What Schulman and his colleagues find is that, notwithstanding the importance of the new research integrity requirements, American academic institutions do not enforce them: "A]cademic institutions rarely ensure that their investigators have full participation in the design of the trials, unimpeded access to trial data, and the right to publish their findings" (Schulman K A, et al, ${ }^{59}$ pp 1335). In an effort to explain this failure, Schulman et al suggest that "t]he current research environment may impede institutions' attempts to negotiate contract provisions that secure investigators' rights" (Schulman K A, et al, ${ }^{59} \mathrm{p} \mathrm{1340)}$ ). The phrase "current research environment" seems to refer euphemistically to the fact that North American (and many European) universities are engaged in competition with each other, and with Contract Research Organisations (CROs), for drug industry research contracts. Contract Research Organisations are private non-academic research groups, to which drug companies can turn, as an alternative to university researchers, in order to conduct the clinical trials needed for government drug licensing. Their costs are usually significantly lower than those of university researchers. Such companies typically have their own research ethics boards, the members of which will be paid by the company. This situation, needless to say, is a breeding ground for conflicts of interest. Contract research organisations with a reputation for producing favourable results for drug companies' products are likely to flourish, while those with more scrupulous standards are likely to go out of business. In other words, universities which are powerfully beholden to drug companies for research sponsorships and donations are not in a strong position to dictate ethical requirements to these same companies. Hence, the widespread failure of universities to meet their institutional obligation to protect research integrity.

As for the recommendations of Bero and Rennie, outlined above, one would have to be of an unshakably optimistic nature to believe that drug companies will voluntarily comply with any of them. This is not because drug companies never behave as good corporate citizens. Some companies are models of socially responsible behaviour. Nevertheless, every publicly traded company has a legal duty to conduct its affairs such that the best interests of its shareholders are given primacy. Alas, the best interests of shareholders do not always coincide with the best interests of patients/research subjects/the general public. When the costs of developing a new drug and bringing it to market fall in the neighbourhood of \$100-\$800 million (US), ${ }^{60-62}$ it would be an unusual drug company that would willingly permit the publication of adverse data likely to scuttle its investment. To repeat an earlier quoted passage from "Dancing with the porcupine": "The duty of universities is to seek truth. The duty of pharmaceutical companies is to make money for their shareholders" (Lewis S, et al, ${ }^{3}$ p 783).

One short and simple solution to the problem of protecting the research integrity of investigators and universities alike would be to prohibit outright the conflicts of interest which are responsible, in large part, for generating the problem. Carl Elliot asks us to contemplate our reaction to a judicial proceeding in which the judge was paid by one of the corporate litigants. ${ }^{48}$ One has only to consider this prospect in order to realise that our judicial system would lose all credibility if such a practice were permitted. We require of the judiciary that it be disinterested and dispassionate. As Sheldon Krimsky points out, in an interview in the Chronicle of Higher Education which was quoted in the CAUT Bulletin (Bulletin of the Canadian Association of University Teachers): "We would not permit a judge...to have equity in a for profit prison, even if the judge disclosed $\mathrm{it}^{\prime \prime}{ }^{63}$
Analogously, biomedical researchers and their universities should simply not be permitted to put themselves into situations of financial conflict of interest. If the community values public science in the public interest then it will have to be paid for by public tax dollars. Other (reformist) solutions, however plausible they may appear, are very unlikely to succeed in practice.

In the long run and overall it cannot serve the public interest to have the research agenda dictated by the corporate imperative of short run profitability. In the long run and overall it cannot be in society's interest to permit universities to forfeit public trust in the objectivity and independence of university research.

This does not mean that university originated discoveries should never be commercialised. In Western marketplace societies, many of the discoveries of fundamental research will be developed and marketed commercially. It should become the job of governments to develop new mechanisms so that a fair share of the resulting profit would be captured for the benefit of universities and hospitals-while avoiding the current funding arrangement whereby a growing number of researchers tends to become handmaidens of business, and universities become adjuncts of large corporations. University research and university researchers must be sequestered from the process of commercialisation if we want to avoid the kinds of damaging conflicts of interest described earlier.

How might such a sequestration be achieved? It would likely be difficult, or even impossible, for any national government unilaterally to change its intellectual property and patent laws. One practical possibility might be to require of any drug company which desires to bring a new drug to market that it provide to an independent institute all the funding necessary for the design and performance of a clinical trial of its drug. The institute would then allocate to qualified university and hospital researchers the task of conducting the necessary clinical trials. Clinical research would thereby become disinterested. Another promising solution to the challenge might lie in changes to the tax system. If industry profitably exploits the public's investment in scientific research, it cannot legitimately complain when a fair share of its profits from such research are recaptured through special taxation. This would constitute a partial answer to the question: if university and hospital research are no longer to be funded by industry, from which alternative source will they draw financial support? The government could provide such support through special taxes raised from corporations which make use of discoveries originating from university scientific research. Working out the details of such a proposal will be no easy task. Problems and obstacles are easy to imagine, but may not be insurmountable if society perceives a need to restore and preserve the integrity of scientific research.

The price tag for this radical proposal - that we revert to a system of public research funding-could be high, especially if it turns out not to be feasible to recapture, through taxation, most of the revenue now generated by commercialisation of university research. But there is an argument to be made that if drug research were publicly funded there would actually be a net saving, because drug costs would, in the absence of patents, be dramatically lower. ${ }^{64}$ It is also important to note, in this connection, that failure to eliminate the conflicts of interest which currently bedevil the biomedical research community also carries a considerable price tag. The evidence on which "evidence based medicine" depends currently falls well short of the key desideratum of scientific reliability. If the status quo or something only mildly better than the status quo persists over time, fortunes of money will be wasted on ineffective or positively harmful treatments, and lives will be lost or blighted. Not so much 
because dishonest researchers will deliberately attempt to foist fraudulent results on the medical community as because ordinary decent researchers will be influenced, often unconsciously, by their understandable desire to please industry sponsors in order to achieve career success and/or financial reward.

Many within the biomedical research community will be inclined to dismiss the sequestration proposal herein advanced as the unrealistic musings of an armchair philosopher. An impartial survey of the evidence, however, can plausibly be interpreted to show that the long term costs of continued university reliance upon industry funding are likely far to outweigh the short term benefits. Certainly, the stakes are high. To continue on our present course is to risk losing the one commodity which, for physicians, universities, and hospitals, should be viewed as beyond price: the public trust.

Disclaimer: The author has not been funded by any drug company. He has appeared at three press conferences with Nancy Olivieri, at which his (unpaid) role was to analyse and evaluate the ethical issues raised by her dispute with Apotex, the Hospital for Sick Children, and the University of Toronto.

Arthur Schafer is Professor of Philosophy at the University of Manitoba and Director of the Centre for Professional and Applied Ethics.

\section{REFERENCES}

1 O'Hara J. Whistleblowing. Maclean's Magazine 1998 Nov:66.

2 Nathan DG, Weatherall DJ. Academic freedom in clinical research. N Engl J Med 2002;347:1368-70.

3 Lewis S, Baird P, Evans RG et al. Dancing with the porcupine: rules for governing the university/industry relationship. CMAJ 2001;165:783-5.

4 Naimark A, Knoppers BM, Lowry FH. Clinical trials of $L 1$ (deferiprone) at The Hospital for Sick Children: a review of the facts and circumstances. Toronto: Hospital for Sick Children, 1998.

5 Thompson J, Baird P, Downie J. Report of the Committee of Inquiry on the case involving Dr Nancy Olivieri, the Hospital for Sick Children, the University of Toronto, and Apotex Inc. Toronto: Canadian Association of University Teachers, 2001.

6 Naimark A, Knoppers BM, Lowy FH. Commentary on selected aspects of the Report of the Canadian Association of University Teachers Committee of Inquiry on the case involving Dr Nancy Olivieri, The Hospital for Sick Children, the University of Toronto and Apotex Inc. Toronto: The Hospital for Sick Children, 2001

7 Thompson J, Baird P, Downie J. Supplement to the Report of the Committee of Inquiry on the case involving Dr Nancy Olivieri, the Hospital for Sick Children, the University of Toronto, and Apotex Inc. Toronto: Canadian Association of University Teachers, 2002.

8 The College of Physicians and Surgeons of Ontario. Complaints committee decision and reasons. Claimant: Dr Laurence Becker; respondent: Dr Nancy Olivieri. 2001 Dec 19: No 44410.

9 Gibson E, Baylis F, Lewis S. Dances with the pharmaceutical industry. CMAJ 2002; 15:36-41

10 Le Carré J. The constant gardener. Toronto: Penguin, 2001.

11 Ranalli P. Courage under fire [letter]. Globe and Mail 1998 Aug 19:A9.

12 Healy D. Good science or good business? Hastings Cent Rep 2000;30:19-22.

13 Elliott C. Throwing a bone to the watchdog. Hastings Cent Rep 2001;31:9-12.

14 Clarke C. Top scientists allege U of T academic chill. The Globe and Mail 2001 Sept 6:A1.

15 Bloch-Nevitt S. Addiction centre stands behind decision on hiring dispute www.newsandevents. utoronto.ca/bin2/0106 (accessed 31 Aug 2001).

16 Creaney W, Murray I, Healy D. Antidepressant induced suicidal ideation. Hum Psychopharmacol 1991;6:329-32.

17 Healy D. The fluoxetine and suicide controversy. CSN Drugs 1994;1:223-31.

18 Healy D. Antidepressant induced suicidality. Primary Care Psychiatry 2000;16:23-8

19 Somerville MA. Post-modern tale: the ethics of research relationships. Nature 2002;1:316-20.

20 Merton RK. The sociology of science. Chicago: University of Chicago Press 1973.

21 Merges RP. Property rights theory and the commons: the case of scientific research. In: Frankel E, Miller FD Jnr, Paul J, eds. Scientific innovation, philosophy and public policy. Cambridge: Cambridge University Press, 1996.

22 Birch DM, Cohn G. The changing creed of Hopkins science. Baltimore Sun 2001 Jun 25:A1.
23 Bok D. Universities in the marketplace. Princeton, NJ: Princeton University Press, 2003:77.

24 Hausman DM, Kitcher P. Science, truth and democracy [book review]. Ethics 2003;13:423-8 at 424

25 Zachary GP. The endless frontier: Vannevar Bush, engineer of the American century. Cambridge: MIT Press, 1999.

26 Diamond v Chakrabarty, US 1980;447:303

27 Haber E. Industry and the university. Nat Biotechnol 1996;14:441-2.

28 Bodenheimer T. Uneasy alliance: clinical investigators and the pharmaceutical industry. N Engl J Med 2000;342:1539-44.

29 Krimsky S. Cited in: Kreeger KY. Studies call attention to ethics of industry support. Scientist 1997;11:1.

30 Pressman L. AUTM licensing survey. FY 1999: survey summary. Northbrook, IL: Association of University Technology Managers. Cited in: Bekelman JE, Li Y, Gross CP. Scope and impact of financial conflicts of interest in biomedical research. JAMA 2003;289:454-65.

31 Anon. The tightening grip of big pharma [editorial]. Lancet 2001;357:1141.

32 Weiss R, Nelson D. Teen dies undergoing experimental therapy. Washington Post 1999 Sept 29:A1.

33 Stelfox HT, Chua G, O'Rourke K, et al. Conflict of interest in the debate over calcium-channel antagonists. N Engl J Med 1998;338:101-6.

34 Bekelman JE, Li Y, Gross CP. Scope and impact of financial conflicts of interest in biomedical research. JAMA 2003;289:454-65.

35 Lexchin J, Bero KA, Djulbegovic B. Pharmaceutical industry sponsorship and research outcome and quality: systematic review. BMJ 2003;326:1 167-74.

36 Diulbegovic B, Lacevic M, Cantor A, et al. The uncertainty principle and industry sponsored research. Lancet 2000;356:635-8.

37 Rochon PA, Gurwitz JH, Simms RW, et al. A study of manufacturer supported trials of non-steroidal anti-inflamatory drugs in the treatment of arthritis. Arch Intern Med 1994;154:157-63.

38 Shenk E. Money+science = ethics problems on campus. The Nation 1999 Mar 22:11-18.

39 Smith ML. Publication bias and meta-analysis. Evaluation Education 1980;4:22-24.

40 Dickersin K. The existence of publication bias and risk factors for its occurrence. JAMA 1990;263:1385-9.

41 Bero LA, Rennie D. Influences on the quality of published drug studies. Int J Technol Assess Health Care 1996;12:209-37, at 209

42 Science, Innovation and Electronic Information Division, Statistics Canada. Estimates of gross expenditures on research and development in the health field in Canada, 1970 to 1998. Ottawa: Statistics Canada, 1999.

43 US Congress, Office of Technology Assessment, Pharmaceutical R\&D. Costs, risks and rewards, OTA-H-522. Washington, DC: US Government Printing Office, 1993: cat no 88F0006XIB99004.

44 Okie S. Missing data on Celebrex. Washington Post 2001 Aug 5:A1 1

45 Dieppe PA, Frankel SJ, Toth B. Is research into treatment of osteoarthritis with non-steroidal anti-inflammatory drugs misdirected? Lancet 1993;341:353-4.

46 Thompson D. Understanding financial conflicts of interest. N Engl J Med 1993:329:573-6.

47 Davis M. Conflict of Interest. Bus Prof Ethics J 1982;1:17-27

48 Elliott C. Pharma buys a conscience. Am Prospect 2001;12:16-20.

49 Avorn J, Chen M, Hartley R. Scientific versus commercial sources of influence on the prescribing behaviour of physicians. Am J Med 1982;73:4-8.

50 Baird P. Getting it right: industry sponsorship and medical research. CMAJ 2003; 168:1267-9.

51 Dukes MNG. Accountability of the pharmaceutical industry. Lancet 2002;360:1682-4.

52 Rawlins MD. Doctors and the drug makers. Lancet 1984;9:11-15.

53 Anon. Avoid financial correctness [editorial]. Nature 1997;385:469.

54 Rothman KJ. Conflict of interest: the new McCarthyism in science [editorial]. JAMA 1993;269:2782-4.

55 Davidoff F, DeAngelis CD, Drazen JM, et al. Sponsorship, authorship, and accountability. N Engl J Med 2001;345:825-7.

56 International Committee of Medical Journal Editors. Uniform requirements for manuscripts submitted to biomedical journals: updated October 2001. http://www.icmie.org/ (accessed 15 Dec 2003).

57 Campbell P. Declaration of financial interests: introducing a new policy for authors of research papers [editorial]. Nature 2001;412:751.

58 Van Kolfschooten F. Can you believe what you read? Nature 2002:416:360-3

59 Schulman KA, Seils DM, Timbie JW, et al. A national survey of provisions in clinical trial agreements between medical schools and industry sponsors. N Engl J Med 2002;347:1335-41.

60 Henry D, Lexchin J. The pharmaceutical industry as a medicines provider. lancet 2002:360:1590-5.

61 DiMasi JA, Hansen RW, Grabowski HG. The price of innovation: new estimates of drug development costs. J Health Econ 2003;22:151-83.

62 Relman A, Angell M. The New Republic 2002 Dec 16:27-42.

63 Anon. Conflicts of interest in biomedical research. CAUT Bulletin 2003 Feb:A9.

64 Baker D, Schmitt J, for Center for Economic and Policy Research. Growing pain: the expense of drugs for the elderly. http://www.cepr.net/ GrowingPain_Issue_Brief.htm (accessed 12 Dec 2003). 